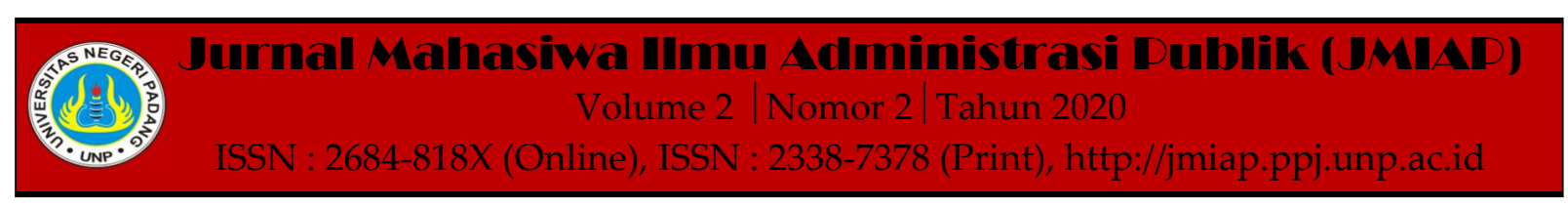

\title{
PERAN DINAS PARIWISATA PROVINSI SUMATERA BARAT DALAM MEWUJUDKAN WISATA HALAL
}

\author{
Rahma Dira Ismail ${ }^{1(a)}$, M. Fachri Adnan ${ }^{2(b)}$ \\ ${ }^{1}$ Jurusan Ilmu Administrasi Negara, Universitas Negeri Padang \\ ${ }^{2}$ Jurusan Ilmu Administrasi Negara, Universitas Negeri Padang \\ a)rahmadira102@gmail.com, b)fachriadnan@fis.unp.ac.id
}

\begin{abstract}
Halal tourism is one of the programs that have been launched by the Sumatra Provincial Government to attract international and domestic tourists since 2016. But until now there has not been any concrete efforts made by the Padang city government in realizing halal tourism in the city of Padang. This study aims to explain the role carried out by the West Sumatra Province Tourism Office in realizing halal tourism in West Sumatra, especially in the city of Padang, which is the capital of the province of West Sumatra, as well as knowing how the obstacles that occur when applying in realizing halal tourism in the city of Padang. This research uses qualitative research type by using descriptive method which is done by purposive sampling. Data collection techniques were carried out with interviews and documentation studies, with informants from several employees of the West Sumatra Province Tourism Office and several stakeholders related to the development of halal tourism in the city of Padang. The role and effort undertaken by the West Sumatra Province Tourism Office is still in the form of providing halal certification to restaurants and restaurants in the city of Padang. The absence of regulations governing halal tourism for regions and regencies in West Sumatra has caused the slow development of halal tourism.
\end{abstract}

Keywords : Government's Role, Halal Tourism, Tourism Office

Corresponding author. Email.rahmadira102@gmail.com,fachriadnan@fis.unp.ac.id

How to cite this article. Ismail, R. Dira \& Adnan, M. Fachri. (2020). Peran Dinas Pariwisata Provinsi Sumatera Barat dalam Mewujudkan Wisata Halal. Jurnal Mahasiwa Ilmu Administrasi Publik (JMIAP) Jurusan Ilmu Administrasi Negara Fakultas Ilmu Sosial Universitas Negeri Padang, Volume 2 (2), Hal. 98-107.

http://jmiap.ppj.unp.ac.id

ISSN : 2684-818X (Online), ISSN : 2338-7378 (Print)

Copyright $(2020$. Published by Pusat Kajian-Pemberdayaan dan Pelayanan Masyarakat (PK-P2M) FIS UNP Padang 


\section{PENDAHULUAN}

Provinsi Sumatera Barat memiliki Sumber Daya Alam yang indah dan kaya seperti pegunungan, danau Maninjau, Singkarak, danau diatas dan dibawah, pantai Mandeh, pantai Bungsu, dan Muaro Padang, serta beberapa pulau yang menghiasi geografis Indonesia. Kekayaan alam yang dimiliki daerah ini dapat menarik wisatawan dalam dan luar negeri untuk berkunjung ke daerah ini. Saat ini Sumatera Barat memiliki objek wisata yang sangat beragam untuk dikunjungi para wisatawan.

Wisata bahari Sumbar mempunyai Pantai Padang dan Pantai Air Manis yang dikenal dengan adanya Batu Malin Kundang. Sementara untuk wisata pulau Sumbar memiliki pilihan seperti pulau Pasumpahan, Pamutusan, dan kawasan mande yang dikenal dengan laut yang masih biru. Dan untuk kunjungan rekreasi pegunungan yaitu di Bukittinggi dengan sejuknya hawa kota hingga pemandangan Ngarai Sianok nan Indah untuk dipandang.

Obyek wisata merupakan kunjungan kesuatu daerah tujuan wisata yang memiliki daya tarik untuk didatangi dan berkunjung ke tempat tersebut. Obyek wisata perlu didukung dengan berbagai fasilitas seperti wc umum yang bersih, pembuangan sampah yang memadai, kebersihan obyek wisata, penyediaan tempat ibadah yang bersih, penyediaan lahan parkir yang aman dan pelayanan wisata yang baik.

Pada tahun 2016, Kementerian Pariwisata telah menetapkan tiga Provinsi di Indonesia sebagai destinasi wisata halal, yakni Sumatera Barat, Aceh dan NTB. Oleh karena itu Dinas Pariwisata Provinsi Sumatera Barat harus melakukan upaya dalam pengembangan pariwisata halal pada tiap-tiap daerah yang terdapat di Sumatera Barat.

Setelah ditetapkan Sumatera Barat sebagai destinasi wisata halal, dengan demikian dibutuhkannya sosialisasi dan penerapan destinsi wisata yang berbasis pariwisata halal di Kota Padang ini. Maka dari itu artikel ini bertujuan membahas peranan Dinas Pariwisata Provinsi
Sumatera Barat dalam mewujudkan wisata halal di Kota Padang.

Pariwisata Halal di Sumatera Barat memiliki konsep pengembangan pariwisata dengan prinsip muslim friendly, artinya para pelaku wisata memberikan jaminan kepada wisatawan muslim bahwa mereka mendapatkan pelayanan yang sesuai dengan syariat agama tanpa mengenyampingkan wisatawan konvensional lainnya yang sudah menjadi pasar sebelumnya.

Konsep pariwisata halal yang muslim friendly ini lebih memberikan jaminan kepada wisatawan muslim dalam berwisata. Indikator yang menjadi acuan seperti tersedianya produk makanan halal dengan adanya logo atau sertifikat halal pada rumah makan dan restoran hotel, tersedianya Mushola atau Masjid yang memudahkan wisatawan muslim untuk beribadah, dan terbebasnya obyek wisata dari minuman beralkhol, kemaksiatan, serta kriminalitas lainnya demi menjamin kenyamanan wisatawan baik muslim maupun non muslim.

Masih lambatnya pengembangan wisata halal di Kota Padang terkait sosialisasi yang diberikan kepada masyarakat atau pelaku usaha, penelitian yang dilakukan (Bernik, 2019) menyatakan pemahaman mengenai halal masih kurang tersosialisasi dengan baik di masyarakat. Banyak pelaku usaha restoran dan rumah makan belum mengetahui hal yang sebaiknya dilakukan untuk menjamin bahwa produk yang disajikan memang benar-benar halal. Oleh karena itu dibutuhkan peran Dinas Pariwisata Provinsi Sumatera Barat dalam memberikan sosialisasi pada pelaku usaha dalam melakukan sertifikasi jamiann produk halal serta mencantumkan logo halal pada rumah makan dan restoran yang ada di Kota Padang.

\section{TINJAUAN PUSTAKA}

\section{Konsep Peran}

Peran menurut (Soekanto, 2012: 212213) peranan (role) merupakan aspek dinamis suatu kedudukan (status). Bagaimana seseorang melaksanakan hak 
dan kewajibannya sesuai dengan kedudukannya dan menjalankan suatu peranan. Hubungan sosial yang terdapat pada masyarakat merupakan peran dari masing-masing individual dalam masyarakat. Maka dari itu peranan Dinas Pariwisata Provinsi Sumatera Barat dalam mewujudkan wisata halal pada artikel ini maksudnya berkaitan dengan apa yang telah dilakukan Dinas Pariwisata Sumatera Barat dalam mewujudkan wiasata halal di Sumatera Barat.

\section{Konsep Pemerintah Daerah}

Pemerintah daerah memiliki wewenang dalam mengurus dan mengatur rumah tangganya sendiri sesuai dengan UndangUndang Nomor 23 Tahun 2014 tentang Pemerintahan Daerah. (Syafiie, 2011: 6364) juga berpendapat bahwa otonomi daerah merupakan hak, wewenang, dan kewajiban suatu pemerintahan daerah untuk mengatur dan mengurs rumah tangganya sendiri. Pemberian otonomi kepada pemerintah daerah haruslah nyata, dinamis, dan bertangungjawab. Dengan demikian dibutuhkannya peran dinas pariwisata sebagai instansi pemerintah daerah dalam membantu dan mengurus pengelolaan dibidang pariwisata untuk pengembangan pariwisata di Kota Padang dalam menunjang kesejahteraan masyarakat melalui kunjungan wisatawan ke Kota Padang.

Perkembangan pariwisata yang terjadi ini karena adanya perubahan dan perbedaan sosial dan budaya, sehingga masyarakat ingin mengunjungi tempat-tempat yang memiliki sejarah atau tempat yang memiliki keindahan alam yang berbeda dengan tempat tinggalnya saat ini. Maka dari itu Dinas Pariwisata berupaya mewujudkan wisata halal di Kota Padang ini untuk dapat mengembangkan Pariwisata yang ada di Kota Padang.

Pengembangan pariwisata ini sejalan dengan perencanaan pembangunan yang dipaparkan oleh (Yomi, 2018) yaitu sejalan dengan perencanaan pembangunan Nasional maka pembangunan parwisata sangatlah dibutuhkan. Pariwisata memiliki banyak manfaat bagi masyarakat dan Negara sekalipun, manfaat pariwsata dapat dilihat dari segi ekonomi, sosial budaya, lingkungan hidup, nilai pergaulan dan ilmu pengetahuan, serta peluang dan kesempatan kerja.

\section{Konsep Pariwisata Halal}

Global Muslim Travel Index tahun 2016 dalam (Subarkah, 2018:54) menyatakan bahwa wisata halal adalah pariwisata yang dijalankan sesuai dengan prinsip-prinsip Islam dengan tujuan memberikan fasilitas dan layanan yang ramah terhadap wisatawan Muslim. Berikut Kriteria Pariwisata Halal menurut Global Muslim Travel Index (GMTI):

\section{Table 1. Kriteria Pariwisata Halal}

\begin{tabular}{|c|c|}
\hline Kategori & Indikator \\
\hline \multirow{4}{*}{$\begin{array}{l}\text { Destinasi Pariwisata } \\
\text { (Alam, Budaya, } \\
\text { Buatan) }\end{array}$} & $\begin{array}{l}\text { Tersedia pilihan aktivitas wisata, seni, dan budaya yang tidak mengarah } \\
\text { pada pornoaksi, dan kemusyrikan }\end{array}$ \\
\hline & $\begin{array}{l}\text { Bila memungkinkan menyelenggarakan minimal satu festival halal life } \\
\text { style }\end{array}$ \\
\hline & Pramuwisata berpakaian dan berpenampilan sopan \\
\hline & $\begin{array}{l}\text { Tersedia pilihan daya tarik wisata pantai dan pemandian yang terpisah } \\
\text { untuk pria dan wanita dan/atau mempunyai aturan pengunjung tidak } \\
\text { berpakaian minim }\end{array}$ \\
\hline \multirow[t]{6}{*}{ Hotel } & Tersedia makanan halal \\
\hline & $\begin{array}{l}\text { Tersedia fasilitas yang memudahkan untuk beribadah, seperti Masjid, } \\
\text { Mushola dan fasilitas bersuci }\end{array}$ \\
\hline & $\begin{array}{l}\text { Tersedia playanan saat bulan Ramadhan untuk memenuhi kebutuhan } \\
\text { sahur dan buka puasa }\end{array}$ \\
\hline & $\begin{array}{l}\text { Tidak adanya aktivitas non-halal seperti perjudian, minuman } \\
\text { beralkhohol, dan kegiatan diskotik }\end{array}$ \\
\hline & $\begin{array}{l}\text { Tersedia fasilitas rekreasi kolam reang dan fasilitas kebugaran/gym yang } \\
\text { terpisah antara pria dan wanita }\end{array}$ \\
\hline & $\begin{array}{l}\text { Bila hotel menyediakan fasilitas spa, maka terapis pria untuk pelanggan } \\
\text { pria dan terapis wanita untuk pelanggan wanita. Terapi tidak } \\
\text { menggunakan bahan yang mengandung babi, alkholol maupun produk } \\
\text { turunannya }\end{array}$ \\
\hline \multirow[t]{5}{*}{ Biro Perjalanan } & $\begin{array}{l}\text { Menyediakan paket wisata yang sesuai dengan kriteria umum Pariwisata } \\
\text { Halal }\end{array}$ \\
\hline & Tidak menawarkan aktivitas non-halal \\
\hline & Memiliki daftar usaha penyedia makanan dan minuman halal \\
\hline & $\begin{array}{l}\text { Pemandu wisata memahami dan mampu melaksanakan nilai-nilai syariah } \\
\text { dalam menjalankan tugas }\end{array}$ \\
\hline & Berpenampilan sopan dan menarik sesuai dengan etika Islam \\
\hline
\end{tabular}

Sumber: Tim Percepatan Pembangunan Pariwisata Halal (Widhasti, Damayanti, \& Sardjono, 2017)

Penyelenggara pariwisata halal adalah pariwisata dengan konsep destinasi ramah muslim yang mendukung ketersediaan produk dan jasa wisata bagi wisatawan 
muslim. Pengembangan pariwisata halal yang diterapkan di Provinsi Sumatera Barat khususnya Kota Padang, yakni lebih mengedepankan terhadap pelayanan yang diberikan kepada wisatawan muslim baik lokal maupun asing. Selain pelayanan yang lebih Dinas Pariwisata juga memberikan jaminan, jamina produk halal yang akan dinikmati wisatawan muslim maupun non muslim, baik itu produk kuliner yang halal, destinasi wisata yang jauh dari maksiat, serta jaminan higienitas dari restoran dan rumah makan yang telah direkomendasikan oleh pihak Dinas Pariwisata.

\section{METODE PENELITIAN}

Penelitian yang digunakan yaitu kualittaif dengan metode desktiptif. Lokasi penelitian dilakukan di Kantor Dinas Pariwisata Provinsi Sumatera Barat. Dengan menggunakan informan penelitian melalui teknik Purposive Sampling yaitu memilih informan yang dapat mengetahui informasi sesuai masalah penelitian. Adapun informan penelitiannya sebagai berikut Kepala Dinas Pariwisata Provinsi Sumatera Barat, Kepala Bidang Pengembangan Destinasi \& Daya Tarik Pariwisata Provinsi Sumatera Barat, Kasi pengembangan Sumber Daya Pariwisata Provinsi Sumatera Barat, Kepala Bidang Pemasaran Dinas Pariwisata dan Kebudayan Kota Padang, dan stakeholder terkait lainnya, serta teknik pengumpulan data dilakukan dengan cara wawancara dan studi dokumentasi.

\section{HASIL DAN PEMBAHASAN}

\section{Peran Dinas Pariwisata dalam mewujudkan wisata halal di Kota Padang}

Dalam peranan yang dilakukan oleh pemerintah daerah ini, disini peneliti lebih mengkaji sudah sejauh mana peran yang diberikan Dinas Pariwisata dalam mewujudkan wisata halal ini. Oleh karena itu agar kita data melihat peran pemerintah daerah yakni Dinas Pariwisata maka peneliti mengkajinya melalui ekosistem destinasi pariwisata halal sebagai berikut: a) Produk dan Pelayanan

Dalam ekosistem destinasi pariwisata halal ada beberapa unsur yang harus diperhatikan seperti atraksi, amenitas dan aksesibilitas. Dina Pariwisata sudah berupaya memenuhi hal itu dalam bentuk memberikan sertifikasi kepada restoran dan rumah makan yang ada di Kota Padang. Dinas Pariwisata Provinsi Sumatera Barat memberikan bantuan berupa subsidi kepada restoran dan rumah makan yang ingin mengurus sertifikasi halal ini. Dorongan dan bantuan seperti inilah yang diharapkan oleh pelaku wisata dalam mewujudkan wisata halal di Kota Padang ini.

Produk dan layanan lainnya yang diberikan Dina Pariwisata Sumatera Barat yaitu memfasilitasi pelaku usaha untuk mengikuti event tingkat internasional yang pernah diadakan di Malaysia yaitu Malaysia Internasional Halal Showcase (Mihas) pada tahun 2018, event ini berupa pameran untuk produk-produk halal, pelaku wisata yang dibawa saat itu ialah Hotel Rangkayobasa dan Pengelola coklat yang ada di Padang-Pariaman. Selanjutnya event lainnya yaitu Malaysia Internasional Travel Mart (MITM), event ini lebih kepada mempromosikan dan memperkenalkan Sumatera Barat sudah pariwisata halal, pelaku usaha yang dibawa oleh Dinas Pariwisata yaitu Agent travel Limpapeh Tour.

Selanjutnya produk dan layanan yang diberikan Dinas Pariwisata dalam bentuk amenitas, atraksi dan aksesibilitas yang dibutuhkan oleh wisatawan muslim dan wisatawan lainnya, seperti pemberian sertifikasi halal yang dilakukan oleh Dinas Pariwisata kepada rumah makan dan restoran halal yang ada di Kota Padang, karena jika wisatawan muslim ingin makanan yang sudah bersertifikasi halal otomatis sudah tersedia, dan untuk wisatawan non muslim juga dapat menikmati makanan halal ini karena bersih, higienis dan tempat yang nyaman. Restoran dan rumah makan yang bersertifikasi halal ini memang harus sesuai dengan aturannya yaitu produk-produk olahan masakannya 
Rahma Dira Ismail, M. Fachri Adnan| Peran Dinas Pariwisata Provinsi Sumatera Barat dalam Mewujudkan Wisata Halal

harus ada lebel halal, dan rumah potongnya juga harus halal, selain dari segi produk dan makann, restoran dan rumah makan halal ini harus menyediakan pelayanan yang ramah dan memiliki wc yang bersih serta air yang mengalir.

Berikut data restoran hotel dan rumah makan yang telah memiliki dan mengurus sertifikasi halal di Kota Padang :

Table 2. Data Restoran Hotel Yang Bersertifikat Halal

\begin{tabular}{|c|l|l|c|c|}
\hline No & $\begin{array}{l}\text { Nama Usaha } \\
\text { Pariwisata }\end{array}$ & \multicolumn{1}{|c|}{ Alamat } & $\begin{array}{c}\text { Tahun } \\
\text { Anggaran }\end{array}$ & Keterangan \\
\hline 1 & $\begin{array}{l}\text { Resto Hotel } \\
\text { Rangkayo Basa }\end{array}$ & $\begin{array}{l}\text { Jl. Hang Tuah No. } \\
\text { 211, Padang }\end{array}$ & 2017 & Subsidi Provinsi \\
\hline 2 & $\begin{array}{l}\text { Resto Hang } \\
\text { Tuah }\end{array}$ & $\begin{array}{l}\text { Jl. Pemuda No. 1 } \\
\text { Padang Barat, Padang }\end{array}$ & 2017 & Subsidi Provinsi \\
\hline 3 & $\begin{array}{l}\text { Resto Grand } \\
\text { Inna Padang }\end{array}$ & $\begin{array}{l}\text { Jl. Gereja No. 34 } \\
\text { Padang }\end{array}$ & 2017 & Subsidi Provinsi \\
\hline 4 & $\begin{array}{l}\text { Restoran Hotel } \\
\text { Ox Ville }\end{array}$ & $\begin{array}{l}\text { Jl. Kp. Sebelah No. } \\
\text { 28 Kel. Berok Nipah } \\
\text { Padang }\end{array}$ & 2018 & Subsidi Provinsi \\
\hline 5 & $\begin{array}{l}\text { Restoran Hotel } \\
\text { Fave }\end{array}$ & $\begin{array}{l}\text { Jl. Belakang Olo No. } \\
46 \text { Padang }\end{array}$ & 2018 & Subsidi Provinsi \\
\hline 6 & $\begin{array}{l}\text { Restoran Hotel } \\
\text { Bunda }\end{array}$ & $\begin{array}{l}\text { J. Bundo Kanduang } \\
\text { No. 19 Padang }\end{array}$ & 2018 & Subsidi Provinsi \\
\hline 7 & $\begin{array}{l}\text { Restoran Hotel } \\
\text { Daima }\end{array}$ & $\begin{array}{l}\text { J. Jend. Sudirman } \\
\text { No. 17 Padang }\end{array}$ & 2019 & Subsidi Provinsi \\
\hline 8 & $\begin{array}{l}\text { Restoran Hotel } \\
\text { Axana }\end{array}$ & $\begin{array}{l}\text { Jl. Bundo Kanduang } \\
\text { No. 14-16 Kota } \\
\text { Padang }\end{array}$ & 2019 & Subsidi Provinsi \\
\hline 9 & $\begin{array}{l}\text { Kestoran Hotel } \\
\text { J. MH. Thamrin No. } \\
71 \text { Ranah Parak } \\
\text { Rumbio, Padang }\end{array}$ & 2019 & Subsidi Provinsi \\
\hline
\end{tabular}

Sumber: Dokumen Dinas Pariwisat)

Table 3. Data Rumah Makan Bersertifikat Halal

\begin{tabular}{|c|c|c|c|c|}
\hline $\mathrm{N}_{0}$ & $\begin{array}{l}\text { Nama Lsaha } \\
\text { Pariwisata }\end{array}$ & Alamat & $\begin{array}{l}\text { Tahun } \\
\text { Anggaran }\end{array}$ & Keterangan \\
\hline 1 & $\begin{array}{l}\text { RM. Lamun } \\
\text { Ombak }\end{array}$ & Jl. Khatib Sulaiman Padang & 2017 & Mandiri \\
\hline 2 & RM. Sari Raso & Jl. Karya No. 3 Padang & 2018 & Mandiri \\
\hline 3 & $\begin{array}{l}\text { Hoya Bakery and } \\
\text { Rest }\end{array}$ & $\begin{array}{l}\text { Nl. Kampung Sebelah } \\
\text { Padang }\end{array}$ & 2018 & Mandiri \\
\hline 4 & RM. Silungkang & $\begin{array}{l}\text { Il. Sawahan, depan stasiun, } \\
\text { Simpang Haru Padang }\end{array}$ & 2018 & Subsidi Provinsi \\
\hline
\end{tabular}

Sumber: Dokumen Dinas Pariwisata
Jadi Dinas Pariwisata telah memberikan produk dan pelayanan kepada pelaku usaha restoran dan rumah makan kerena telah membantu memberikan subsidi untuk melakukan sertifikasi halal kepada restoran dan rumah makannya. Berikut data restoran dan rumah makan yang telah bersertifikasi halal di Kota Padang.

b) Dukungan Pemerintah

Dinas Pariwisata Provinsi Sumatera Barat selalu memberikan dukungan terhadap pengembangan pariwisata yang ada di Sumatera Barat termasuk Kota Padang. Untuk pengelolaan destinasi pariwisata halal ini memang belum bisa ditangani oleh pemerintah Kabupaten atau Kota, karena pengembangan pariwisata halal ini masih ditangani oleh pihak Provinsi karena kebijakan dan regulasi yang baru saja selesai. Setelah adanya perda penyelenggaraan pariwisata halal yang baru disahkan pada tanggal 9 Juni 2020 ini, barulah pemerintah kabupaten atau kota dapat berkaca dan mengacu kepada perda ini dalam membuat regulasi untuk daerahnya masing-masing.

Mulai dari tahun 2016 Sumatera Barat dinobatkan oleh Kementerian Pariwisata sebagai destinasi pariwisata halal. Pada tahun itulah Dinas Pariwisata mencoba untuk melakukan sosialisasi guna untuk menyatukan pendapat bahwa apakah kita membutuhkan peraturan halal ini atau tidak, apakah wisata halal ini perlu diformalkan atau tidak. Memang ada pro dan kontra dalam pembuatan perda ini, mulai dari pemahaman mengenai halal yang mengganggu wisatawan non muslim, hingga menyatukan antara wisata halal dan wisata syariah padahal itu dua hal yang berbeda. Selanjutnya pada tahun 2017 pemerintah sudah melakukan kegiatan sosialisasi wisata halal, setelah itu tahun 2018 penyusunan perda, dan di tahun 2019 barulah di proses oleh DPRD, barulah pada tahun 2020 ini disahkannya Perda mengenai Penyelenggara Pariwisata Halal Provinsi Sumatera Barat. 
Selanjutnya Nusa Tenggara Barat yang telah memiliki Perda dalam (Hamzana, 2018:6) menyatakan bahwa pelaksanaan standarisasi pariwisata halal di NTB sudah mulai menunjukan peningkatan pada aspek restoran. Signifikansi peningkatan angka pelaksanaan standarisasi pariwisata halal terjadi pada tahun 2016, hal ini berkaitan dengan dikeluarkannya Perda NTB No. 2 Tahun 2016 tentang Pariwisata Halal. Hal ini berbeda dengan Perda Sumbar mengenai penyelenggaraan pariwisata halal yang baru disahkan menyebabkan masih lambannnya pelaksanaan pengembangan pariwisata halal di Sumatera Barat ini, sedangkan di Nusa Tenggara Barat sudah lama memiliki Perda tentang Pariwisata Halal membuat perkembangan pariwisata halal di daerah itu menjadi berkembang pesat.

Pada prinsipnya Dinas Pariwisata sudah melakukan beberapa kali pelatihan dan sosialisasi, lalu Dinas Pariwisata sudah membuat rencan aksi untuk pariwisata halal ini agar semua bergerak baik akademisi, kemudian pemerintah, lalu industry pariwisata, kemudian kelompok masyarakat, dan media massa.

\section{c) Infrastruktur}

Infrastruktur sangat dibutuhkan untuk menunjang kelancaran dari sebuah pembangunan termasuk destinasi pariwisata. Dalam membangun destinasi pariwisata khususnya wisata halal, dibutuhkan tempat-tempat ibadah yang layak dan bersih, serta menyediakan perlengkapan untuk beribadah yang bersih dan nyaman, memiliki wc terpisah antara pria dan wanita serta terdapat air mengalir di dalamnya.

Selanjutnya hal tersebut juga dipaparkan dalam (Ghani, 2017) menyampaikan bahwa sarana dan prasarana pariwisata merupakan unsur yang dapat memudahkan dan membantu proses kegiatan dalam berwisata agar berjalan lancar, yang mencakup dari Tour operator, angkutan wisata, Travel Agent, rumah makan, akomodasi seperti hotel/penginapan, obyek wisata, atraksi wisata serta prasarana seperti fasilitasi aksesibilitas, toilet, dan petugas keamanan. Sesuai dengan transportasi yang ada di Kota Padang ini sudah cukup lancar dan baik. Wisatawan yang ingin berlibur ke Kota Padang bisa melalui jalur darat, laut, dan udara. Karena Kota Padang memiliki Bandara Internasional yang bisa mendatangkan turis-turis asing, memiliki pelabuhan yang aktif, dan jalur darat yang baik, sehingga wisatawan lokal maupun asing bisa masuk ke Kota Padang dengan jalur apapun yang digunakan. Destinasi wisata di Kota Padang untuk jalan rata-rata sudah memenuhi kriteria infrastruktur yang baik, hanya saja jalan ke tempat wisata Pantai Air Manis yang masih kurang bagus, karena terletak di pemukiman warga yang jauh dari pusat kota.

Restoran Hotel Rangkayobasa sangat antusias dalam mengurus sertifikasi halal, karena sudah dari tahun 2016 Restoran Hotel Rangkayo Basa mengurus sertifikasi halal ini. Hal ini dikaitkan dengan tamu hotel di rangkayobasa menanyakan bukti halal dari produk makanan yang disediakan di Hotel Rangkayobasa. Maka dari itu disamping Hotel Rangkayobasa sudah berbasis syariah dan alangkah lebih baik dan lebih komplit jika restoran dari hotel tersebut diberi sertifikat halal, agar memberikan jaminan kepada tamu hotel yang sesuai dengan standar halal tersebut.

Pemberian sertifikat halal kepada restoran dan rumah makan juga termasuk infrastruktur yang menunjang pariwisata halal ini. Karena adanya sertifikat halal yang terpajang di restoran dan rumah makan tersebut menandakan penjaminan masakan yang bersih sehat dan halal. Seperti Rumah Makan Silungkang yang telah mengurus sertifikasi halal dan menempelkan logo halal tersebut di depan rumah makannya agar memberitahu konsumen atau wisatawan bahwa produk yang dihidangkan di rumah makan silungkang sudah memiliki jaminan halal.

d) Sumber Daya Manusia

Dalam mendukung destinasi pariwisata halal dibutuhkan peran masyarakat 
khususnya pelaku usaha sebagai pendukung setiap institusi usaha pariwisata halal, serta untuk lembaga pemerintah dibutuhkan sebagai bertugas melakukan sertifikasi produk pariwisata halal. Tanpa adanya sumber daya manusia yang kompeten pariwisata juga tidak akan berkembang dengan pesat, maka dari itu pihak akademisi memberikan silabus atau materi pengajaran tentang pariwisata halal. (Rahtomo, 2018:65) menyebutkan bahwa pembinaan sumber daya manusia dapat mendorong dan meningkatkan kualitas kinerja serta produktivitas diri sendiri maupun dalam berorganisasi.

Dalam kegiatan pariwisata halal ini SDM yang berperan yaitu Dinas Pariwisata dan dari pihak LP POM MUI dalam pengurusan sertifikasi halal. Dinas pariwisata memberikan fasilitas dan insentif dalam pengurusan sertifikasi halal pada restoran dan rumah makan, sementara LP POM MUI mengecek standar dari produk halal yang akan dikonsumsi. Selanjutnya LP POM MUI juga melakukan pengecekan setiap 6 bulan sekali pada restoran dan rumah makan yang telah tersertifikasi halal. Satriana dalam (Destiana \& Astuti, 2019:343) juga menyampaikan hal yang sama yaitu pengembangan pariwisata halal melalui sertifikasi halal oleh LP POM MUI, berkerjasama dengan banyak pihak antara lain DSN (Dewan Syariah Nasinal), MUI (Majelis Ulama Indonesia) dan Lembaga Sertifikasi Usaha, selanjutnya pelatihan SDM, sosialisasi, capacity building dan memgikuti ajang promsi pada kelas Internasional.

Sesuai dengan indikator pariwisata halal maka didapatkan hasil sebagai berikut:

1) Kategori Destinasi Pariwisata

Destinasi pariwsata halal sudah menyediakan fasilitas seperti tersedianya tolilet terpisah antara pria dan wanita dan adanya mushola-mushola dibeberapa titik di Pantai Padang untuk kemudahan wisatawan muslim beribadah ketika sudah masuk waktu sholat, selain musholamushola juga terdapat masjid-masjid besar yang berada di sekitar daerah Pantai
Padang. Indikator lainnya seperti penyediaan produk makanan halal sudah direalisasikan dibeberapa rumah makan dan restoran hotel yang ada di Kota Padang dengan logo halal dan sertifikasi halal yang sudah terpampang pada rumah makan dan restoran hotel tersebut.

Dalam (Yomi, 2018:9) mendapatkan hasil bahwa event dilakukan untuk menarik wisatawan berupa Pacu Jawi, event ini diharapkan akan menjadi faktor pendukung dalam pengembangan obyek wisata di Nagari Tuo Pariangan. Sedangkan Kota Padang belum memiliki event khusus pada kategori pariwisata halal yang dapat menjadi daya tarik pariwisata di Kota Padang.

2) Kategori Hotel

Di Kota Padang ini sudah ada hotel yang mengarah kepada indikator pariwisata halal, seperti sudah tersedianya makanan yang berlabel halal pada restoran hotel. Hotel Rangkayo Basa yang terletak di Jl. Hang Tuah, Kecamatan Padang Barat Kota Padang sudah berbasis syariah, dan lebih mengutamakan pelayanan kepada wisatawan muslim seperti penampilan seluruh staff dan petugas hotel yang sopan dan rapi serta menutup aurat, tidak menyediakan minuman beralkohol, tidak tersedianya kolam berenang karena menghindari bercampurnya antara wisatawan pria dan wanita, serta tersedianya ruang sholat yang besar, memadai dan nyaman.

Selanjutnya untuk Hotel Daima yang sudah memiliki sertifikasi halal pada restoran hotelnya juga terdapat tempat sholat yang berukuran cukup memadai namun masih layak dan nyaman untuk wisatawan muslim beribadah. Berbeda dengan Hotel Mercure yang belum memiliki sertifikasi halal untuk restoran hotelnya dan tempat ibadah yang tidak prioritas dan efektif karena terletak di basement hotel tersebut.

3) Kategori Biro Perjalanan

Biro perjalanan wisata direkomendasikan agar membawa wisatawan ke tempat-tempat yang sudah 
sesuai izin oleh Dinas Pariwisata seperti hotel yang sudah memiliki restoran berlogo halal, membawa wisatawan ke rumah makan yang sudah tersertifikasi halal, hotel yang bersifat syariah, meyediakan waktu yang cukup bagi wisatawan untuk menunaikan sholat wajib ketika dalam perjalanan seperti ke masjid pilihan yang ada di Kota Padang yakni Masjid Raya Sumatera Barat.

\section{Faktor pendukung dan penghambat dalam mewujudkan wisata halal di Kota Padang}

Didalam sebuah perencanaan kegiatan akan selalu ada faktor pendukung dan penghambat yang terjadi saat ingin mewujudkan atau merealisasikan suatu kegiatan tersebut. Faktor pendukung dalam mewujudkan wisata halal ini seperti pelaku usaha yang telah mengikuti sosialisasi mengenai sertifikasi halal untuk restoran dan rumah makan yang ada di Kota Padang. Rumah makan dan restoran hotel yang sudah tersertifikasi halal merupakan faktor dukungan dari pelaku usaha dalam mewujudkan wisata halal, karena sertifikasi produk makanan halal termasuk penunjang dalam pariwisata halal. Dukungan lainnya seperti budaya minangkabau dan semboyan yang dikenal dengan adat basandi syarak, syarak basandi kitabullah, yang mana nilainilai islam telah melekat erat pada masyarakat minangkabau dan bisa dilihat dari segi pakaian yang rata-rata menutup aurat.

Selain falsafah hidup orang minang yang sudah korelasi dengan pariwsata halal dan dukungan yang dilakukan oleh masyarakat di Kota Padang masih terdapat beberapa faktor penghambat dan kendala seperti mindset masyarakat yang masih sempit dalam mengartikan pariwisata halal itu sendiri. Beberapa pelaku usaha tidak ingin mengikuti sertifikasi halal untuk restoran dan rumah makan yang mereka miliki, mereka beranggapan bahwa mereka sudah halal, untuk apa sertifikat halal. Pada kenyatannya tidak demikian, wisatawan membutuhkan bukti dan jaminan yang nyata mengenai produk halal, pemberian sertifikasi halal dan logo halal yang ditempel dan dipajang di rumah makan dan restoran membuktikan bahwa produk yang disediakan sudah memiliki jaminan halal.

Selanjutnya faktor penghambat yang sangat berpengaruh yakni dari pelaku usaha, dukungan untuk rumah makan yang layak bersih masih minim, restoran dan rumah makan yang belum bisa dikatakan layak bersih ini tidak ingin mengurus sertifikasi halal yang disediakan oleh pemerintah. Kembali lagi kepada mindset masyarakat yang berfikir tanpa sertifikasi halal pun mereka sudah halal. Kesadaran masyarakat ataupun pelaku usaha khususnya rumah makan dan restoran masih kurang, hal ini bisa dilihat bahwa hanya sekitar 30 rumah makan dan restoran yang mengurus sertifikasi halal, padahal rumah makan dan restoran yang tercatat ada sebanyak 1300. Hal ini memang diharapkan dukungan dari masyarakat dan dorongan dari pemerintah Kabupaten atau Kota jika regulasi pariwisata halal ini sudah bisa di publikasikan.

Kurangnya kesadaran masyarakat juga terdapat pada pengembangan pariwisata halal di Nusa Tenggara Barat dalam (Hamzana, 2018:12)menyatakan bahwa kurangnya kesadaran masyarakt dalam pengurusan sertifkasi halal cukup mempengaruhi peningkatan pariwisata halal di Nusa Tenggara Barat. Sehingga tugas dan kewajiban pemerintah daerah semakin sulit jika masyarakat tidak berperan dalam melakukan percepat peningkatan pariwisata halal di NTB. Begitupun yang terjadi di Sumatera Barat, guna mempercepat peningkatan pariwisata halal pentingnya meningkatkan kesadaran masyarakat agar mendorong dan berkerjasama dalam melakukan sertifikasi halal ini.

Selain mindset dan kesadaran masyarakat, anggaran juga menjadi penghambat dalam mewujudkan wisata halal ini. Tentu pihak Kabupaten atau Kota tidak memiliki anggaran yang cukup dalam melakukan merenovasi atau melakukan perbaikan fasilitas yang sesuai dengan 
kriteria pariwisata halal itu sendiri. Kemudian dalam melakukan sosialisasi pihak Dinas Pariwisata Provinsi juga membutuhkan anggaran yang lebih, karena saat melakukan sosialisasi ataupun workshop mengenai wisata halal ini, Dinas Pariwisata selalu mendatangkan pemateri yang memang ahli dibidang pariwisata halal ini, tentu hal itu membutuhkan anggaran seperti uang saku, penginapan dan transportasi dari pemateri tersebut. Kendala anggaran mengakibatkan terhambatnya kegiatan sosialisasi yang ingin dilakukan Dinas Pariwisata.

Maka dari itu dengan adanya peran dari Dinas Pariwisata Provinsi Sumatera Barat dalam mengembangkan wisata halal khususnya di Kota Padang, diharapkan pihak Dinas Kota lebih gencar dan signifikan lagi dalam melakukan pengembangan pariwisata halal ini. Karena keterbatasan pelaksanaan kegiatan yang dapat dilakukan pihak Provinsi menyebakan belum maksimalnya pengembangan wisata halal yang ada di Kota Padang sesuai dengan indikator wisata halal itu sendiri.

Pada hakikatnya wisata halal ini menyediakan jaminan yang cukup kuat untuk wisatawan muslim dalam berwisata kemanapun dan dimanapun. Seperti penelitian yang dilakukan oleh (Rismawanti, 2016) mengenai place branding di Pulau Lombok sebagai destinasi wisata halal, upaya place branding itu sendiri dilakukan dengan cara hotel, travel dan restoran, pembenahan spot wisata yang sesuai wisata halal dan melakuakn sertifikasi pada restoran hotel yang ada. Sama halnya dengan yang dilakukan oleh Dinas Pariwisata Provinsi Sumatera Barat dalam pemberian sertifikasi pada restoran dan rumah makan, hanya saja pemerintah Kota Padang belum dapat bergerak dalam melakukan Place Branding destinasi wisata yang ada di Kota Padang karena belum adanya regulasi yang mengatur mengenai wisata halal yang ada di Kota Padang.

\section{PENUTUP}

Peran Dinas Pariwisata Provinsi Sumatera Barat dalam mewujudkan wisata halal ini belum sepenuhnya berperan karena Dinas Pariwisata mendata rumah makan dan restoran yang ada sebanyak 1300, namun yang melakukan pengurusan sertifikasi halal hanya 30 restoran dan rumah makan saja. Hal ini menyatakan bahwa kurangnya sosialisasi yang diberikan Dinas Pariwisata sehingga pelaku usaha tidak gencar dalam melakukan sertifikasi halal pada rumah makan ini.

Upaya yang dilakukan oleh Dinas Pariwisata Provinsi Sumatera Barat, dalam mewujudkan wisata halal yaitu membuat regulasi hingga telah disahkan regulasi mengenai Penyelenggaraan Pariwisata Halal itu pada tanggal 9 Juni 2020 dan telah melakukan sertifikasi halal pada rumah makan dan restoran hotel yang ada di Kota Padang. Pemberian logo halal dan sertifikasi halal ini dilakukan degan cara pengecekan pengolahan limbah dapur, menggunakan produk masak berlebel halal, menyediakan fasilitas toilet yang memiliki air mengalir, terdapat tempat yang bersih dan nyaman, karena halal itu sendiri juga mencakup kedalam higienitas dari sebuah produk itu sendiri. Restoran dan rumah makan yang telah memiliki logo halal di Kota Padang sudah dapat ditemukan dibeberapa tempat seperti rumah makan lamun ombak dan rumah makan silungkang, serta logo halal untuk restoran dapat ditemukan pada restoran hotel Rangkayo Basa.

Produk dan pelayanan yang telah diberikn Dinas Pariwisata yaitu memberikan insentif pada restoran dan rumah makan yang mengurus sertifikasi halal serta memfasilitasi agent travel Limpapeh Tour dalam acara Malaysia Internatioanl Travel Mart untuk mempromosikan pariwisata halal Sumatera Barat di tingkat Internasional. Kurangnya hotel yang sesuai dengan kategori pariwisata halal, hanya Hotel Rangkayobasa yang berbasis syariah di Kota Padang untuk melengkapi akomodasi 
yang diperlukan oleh wisatawan. Dinas Pariwisata memiliki SDM terkait pengembangan pariwisata halal seperti akademisi, kemudian pemerintah, lalu industri pariwisata, kemudian kelompok masyarakat, dan media massa untuk membantu pengembangan pariwisata halal yang ada di Kota Padang

\section{DAFTAR KEPUSTAKAAN}

Bernik, M., R Indika, D., \& Komala Dewi, R. (2019). Standar Penerapan Wisata Halal Bagi Pelaku Industri Pariwisata di Kota Bandung. Jurnal Pemberdayaan Masyarakat Madani (JPMM).

https://doi.org/10.21009/jpmm.003.1.0 6

Destiana, R., \& Astuti, R. S. (2019). Pengembangan Pariwisata Halal di Indonesia. Collaborative Governance Dalam Pengembangan Pariwisata Di Indonesia.

Ghani, Y. A. (2017). Pengembangan Sarana Prasarana Destinasi Pariwisata Berbasis Budaya di Jawa Barat. Jurnal Pariwisata.

Hamzana, A. A. (2018). Pelaksanaan Standarisasi Pelayanan Pariwisata Halal dalam Pengembangan Pariwisata di Nusa Tenggara Barat. Pena Justisia: Media Komunikasi Dan Kajian Hukum.

https://doi.org/10.31941/pj.v17i2.545

Rahtomo, R. W. (2018). Ekosistem Destinasi Pariwisata Halal Wadah Pengembangan Destinasi Pariwisata Ramah Muslim. Jurnal Kepariwisataan: Destinasi, Hospitalitas Dan Perjalanan. https://doi.org/10.34013/jk.v2i2.22
Soekanto, S. (2012). Sosiolgi Suatu Pengantar. Jakarta: Rajawali Pers.

Subarkah, A. R. (2018). Potensi dan Prospek Wisata Halal Dalam Meningkatkan Ekonomi Daerah (Studi Kasus: Nusa Tenggara Barat). In Jurnal Sospol.

Syafiie, I. K. (2011). Sistem Pemerintahan Indonesia. Jakarta: Rineka Cipta.

Widhasti, G. B., Damayanti, C., \& Sardjono, H. S. (2017). Diplomasi publik Pemerintah Republik Indonesia melalui pariwisata halal. Solidaritas Jurnal Ilmu-Ilmu Sosial.

Yomi, W. G., Adnan, M. F., \& Alhadi, Z. (2018). PENGEMBANGAN OBJEK WISATA NAGARI TUO PARIANGAN OLEH DINAS PARIWISATA PEMUDA DAN OLAHRAGA KABUPATEN TANAH DATAR. JPSI (Journal of Public Sector Innovations). https://doi.org/10.26740/jpsi.v3n1.p611

Undang-Undang Republik Indonesia Nomor 10 Tahun 2009 Tentang Kepariwisatan.

Undang-Undang Republik Indonesia Nomor 23 Tahun 2014 Tentang Pemerintahan Daerah.

Undang-Undang Republik Indonesia Nomor 33 Tahun 2014 Tentang Jaminan Produk Halal.

Peraturan Daerah Provinsi Sumatera Barat Nomor 3 Tahun 2014 Tentang Rencana Induk Pembangunan Kepariwisataan Provinsi Sumatera Barat Tahun 20142025 . 